\title{
Aktivitas Antihiperurisemia Ekstrak Etanol Daun Sungkai (Peronema canescens Jack) Pada Mencit Putih Jantan
}

\section{Antihyperuricemia Activity of Ethanol Extract of Sungkai Leaves- (Peronema canescens Jack) in Male White Mice}

\author{
Madyawati Latief ${ }^{1 *}$, Indra Lasmana Tarigan', Putri Maya Sari $^{2}$, Fiolita Etsa Aurora ${ }^{2}$ \\ ${ }^{1}$ Program Studi Kimia, Jurusan Matematika dan Ilmu Pengetahuan Alam, FST, Universitas Jambi \\ ${ }^{2}$ Program Studi Farmasi, Jurusan Farmasi, FKIK, Universitas Jambi \\ J1. Jambi Ma. Bulian, KM.15, Muaro Jambi, Indonesia \\ *Corresponding author: madyawatilatief@unja.ac.id
}

Received: 10 Desember 2020; Accepted: 17 Juni 2021; Published: 30 Juni 2021

\begin{abstract}
Abstrak
Hiperurisemia merupakan penyakit yang diakibatkan peningkatan kadar asam urat dalam darah. Dewasa ini dikembangkan berbagai pengobatan dengan menggunakan bahan alam sebagai salah satu antihiperurisemia. Salah satu bahan alam yang dapat dijadikan sebagai pengobatan antihiperurisemia yaitu daun sungkai (Peronema canescens Jack.). Penelitian ini bertujuan untuk menentukan aktivitas antihiperurisemia ekstrak etanol daun Sungkai. Hewan uji yang digunakan pada penelitian ini adalah mencit putih jantan galur Wistar. Penelitian ini menggunakan rancangan acak lengkap (RAL) dengan 5 kelompok yang terdiri dari kontrol negatif ( $\mathrm{Na} \mathrm{CMC} 0,5 \%$ ) kontrol positif (allopurinol $10 \mathrm{mg} / \mathrm{kgBB}$ ), perlakuan 1 (ekstrak $125 \mathrm{mg} / \mathrm{kgBB}$ ), perlakuan 2 (ekstrak $250 \mathrm{mg} / \mathrm{kgBB}$ ) dan perlakuan 3 (ekstrak $500 \mathrm{mg} / \mathrm{kgBB}$ ). Parameter yang dilihat adalah kadar asam urat yang diukur dengan menggunakan metode POCT (Point of Care Test) serta dianalisis menggunakan analisis statistik One Way Anova dan uji lanjut Duncan. Hasil penelitian menunjukkan kelompok perlakuan dosis $125-500 \mathrm{mg} / \mathrm{kgBB}$ dapat menurunkan kadar asam urat pada mencit dan dosis yang paling baik dalam menurunkan kadar asam urat mencit adalah dosis 500 $\mathrm{mg} / \mathrm{KgBB}$ dengan persen penurunan $38,66 \%$.
\end{abstract}

Kata Kunci: Antihiperurisemia, Ekstrak Etanol, Sungkai ( $P$. canescens Jack)

\begin{abstract}
Hyperuricemia is a disease caused by an increase in uric acid levels in the blood. Currently, various treatments are developed by utilizing natural ingredients as an anti-hyperuricemia. Sungkai (Peronema canescens Jack) is one of the plants that contain a natural compound that can use as an anti-hyperuricemia treatment is the leaves of sungkai (Peronema canescens Jack.). The aim of this study to determine the antihyperuricemia activity of the ethanol extract of Sungkai leaves. The test animals used in this study were male white mice Wistar strain. This study used a completely randomized design (CRD) with 5 groups consisting of negative control ( $\mathrm{Na} \mathrm{CMC} \mathrm{0.5 \% )} \mathrm{positive} \mathrm{control} \mathrm{(allopurinol} 10 \mathrm{mg} / \mathrm{kg} \mathrm{BW}$ ), treatment 1 (extract $125 \mathrm{mg} /$ $\mathrm{kg} \mathrm{BW}$ ), treatment 2 (extract $250 \mathrm{mg} / \mathrm{kg} \mathrm{BW}$ ) and treatment 3 (extract $500 \mathrm{mg} / \mathrm{kg} \mathrm{BW}$ ). The parameters seen were uric acid levels measured using the POCT (Point of Care Test) method and analyzed using One Way Anova statistical analysis and Duncan's continued test. Our results showed that the treatment group with a dose of 125-500 mg / Kg BW reduce uric acid levels in mice. The best dose was a dose of $500 \mathrm{mg} / \mathrm{Kg} \mathrm{BW}$ in reducing uric acid levels in mice with percent decline of $38.66 \%$.
\end{abstract}

Keywords: Antihyperuricemia, Ethanol Extract, Sungkai (P. canescens Jack)

\section{PENDAHULUAN}

Prevalensi hiperurisemia (asam urat) pada saat ini mengalami peningkatan di seluruh dunia dan di Indonesia (Hardian dkk., 2014). Indonesia diketahui memiliki tingkat prevalensi penyakit gout mencapai 6$13,6 / 100.000$ orang, dan terus mengalami peningkatan seiring dengan meningkatnya usia (Krisyanella et al., 2019). Global Burden of Diseases (GBD) melaporkan tingkat prevalensi hiperurisemia di Indonesia mencapai 18\% (Kristiani dkk., 2013; Kusuma dkk., 2014). Hiperurisemia merupakan produk akhir (ekskresi) dalam tubuh terhadap proses 
degradasi purin, sebagai produk buangan dan tidak memiliki fungsi fisiologis. Proses terjadinya hiperurisemia dapat dilihat melalui profil darah, adanya peningkatan kadar asam urat di dalam darah dan melebihi kadar normalnya (pria di atas 7,0 mg/dL dan pada wanita di atas $6,0 \mathrm{mg} / \mathrm{dL}$ ). Perilaku konsumsi menjadi salah satu faktor penyebab hiperurisemia, seperti konsumsi lemak, margarin, santan, mentega, dan beberapa buah-buahan yang diketahui mengandung kadar lemak yang tinggi (durian dan alpukat) juga berpengaruh terhadap pengeluaran asam urat (Suhendi et al., 2011; Dwitiyanti dkk., 2019).

Penumpukan asam urat dalam jaringan tubuh dapat terjadi akibat akumulasi asam urat yang meningkat dalam tubuh secara berkelanjutan, kemudian membentuk kristal urat yang ujungnya tajam seperti jarum. Kondisi ini memacu terjadinya respon inflamasi dan diteruskan dengan serangan gout. Selain itu adanya penumpukan asam urat akan menimbulkan kerusakan hebat pada sendi dan jaringan lunak dan dapat menyebabkan nefrolithiasis urat (batu ginjal) dengan disertai penyakit ginjal kronis jika tidak mendapatkan penanganan yang tepat dan segera (Fitrya and Muharni, 2014; Hardian dkk., 2014; Wahyuningsih et al., 2016).

Umumnya upaya pengobatan hiperurisemia menggunakan obat sintetik seperti allopurinol, dengan menghambat aktivitas enzim xantin oksidase. (XO) Selanjutnya, enzim XO akan mengubah hipoxantin menjadi xantin dan selanjutnya diubah menjadi asam urat (Hardian dkk., 2014; Alpiansyah, 2015). Masyarakat yang semakin mengetahui efek samping yang berbahaya dari penggunaan obat sintetik, menyebabkan masyarakat mencari alternatif obat berbasis bahan alam (terutama tumbuhan) yang relatif lebih aman dan efek sampingnya rendah.

Indonesia merupakan negara yang memiliki kekayaan alam yang melimpah, banyak tumbuhan endemik disetiap daerah di Indonesia yang diketahui memiliki banyak manfaat dalam pencegahan maupun pengobatan suatu penyakit. Salah satu bahan alam yang sering dimanfaatkan sebagai obat tradisional yaitu daun sungkai (Peronema canescens Jack.) (Soetisna, 2005; Imelda et al., 2007; Ahmad and Ibrahim, 2013; Pada et al., 2013). Tumbuhan $P$. canescens merupakan salah satu tumbuhan etnobotani yang digunakan sebagai sumber obat tradisional masyarakat, dan bersifat khas (endemik) Indonesia. $P$. canescens dapat ditemukan di Sumatera dan Kalimantan. Potensi $P$. canescens dapat dikembangkan sebagai obat antihiperurisemia. Secara tradisional masyarakat masih sebatas memanfaatkan sebagai pengobatan pada malaria dan demam, tetapi eksplorasi kandungan senyawa bioaktifnya masih belum dilakukan.

Hasil penelitian sebelumnya melaporkan bahwa terdapat senyawa bioaktif dari ekstrak $P$. cannescens golongan flavonoid, alkaloid, steroid, fenolik, tanin, dan saponin. Senyawa flavonoid diketahui dapat menurunkan kadar asam lemak dengan menghambat aktivitas enzim XO (Fitri dkk., 2017; Roumeliotis et al., 2019). Senyawa novel flavonoid sungkai diduga memiliki aktivitas sebagai antihiperurisemia. Penelitian sebelumnya yang dilakukan pada tumbuhan satu famili dengan tumbuhan sungkai yaitu tanaman kumis kucing (Orthosiphon stamineus) menunjukkan bahwa senyawa flavonoid ekstrak kumis kucing menurunkan kadar asam urat dalam darah pada dosis $0,5 \mathrm{~g} / \mathrm{kgBB}$ (Arafat et al., 2008).

Penelitan mengenai eksplorasi senyawa bioaktif dari tanaman $P$. cannescens masih jarang dilakukan, sehingga dalam penelitian ini dilakukan pengujian aktivitas antihiperurisemia ekstrak etanol daun $P$. cannescens terhadap mencit putih jantan (Mus musculus) terinduksi asam urat menggunakan kalium oksanat dan jus hati ayam.

\section{METODE PENELITIAN}

Bahan dan Peralatan 
Beberapa alat yang digunakan dalam penelitian ini adalah botol minum mencit, sonde (alat infus minuman melalui oral), waterbath, timbangan, alat-alat gelas, rotary evaporator (Eyela), tabung reaksi (Pyrex), oven, grinder (HX-20), blender, neraca analitik (O'haus), alat pengukur kadar asam urat (MultiCheck), test strip uric acid (MultiCheck).

Bahan yang digunakan berupa ekstrak etanol daun sungkai (Peronema canescens Jack.), Kalium Oksonat (pa), hati ayam, Na-CMC, Allopurinol (pa), Aquadest, Ethanol (70\%), N-heksan (pa), Etil asetat (pa), eter (pa), $\mathrm{FeCl}_{3}, \mathrm{Mg}$, pereaksi Dragendorf, pereaksi Meyer, pereaksi Wagner, amonia, $\mathrm{H}_{2} \mathrm{SO}_{4}, \mathrm{HCl}$ $2 \mathrm{~N}, \mathrm{CHCl}_{3}$ dan mencit putih jantan (Mus musculus) galur wistar berumur 3-4 bulan dengan bobot antara 20-30 gram.

\section{Rancangan Penelitian}

Pada penelitian ini digunakan 45 ekor mencit, dibagi secara acak menjadi 5 kelompok, masing-masing 3 ekor dan dilakukan pengulangan sebanyak 3 kali. Hewan percobaan diaklimatisasi selama 7 hari dengan tujuan untuk mengadaptasikan mencit pada lingkungan dan perlakuan yang baru, serta tidak terjadi perubahan berat badan sampai dengan 10\% (BPOM, 2014).

\section{Metode Penelitian}

Pembuatan Simplisia Daun Sungkai

Sampel yang digunakan adalah daun sungkai, diambil dari Kecamatan kumpeh, Kabupaten Muaro Jambi, Provinsi Jambi. Daun sungkai segar diambil sebanyak 4,5 Kg langsung dari pohonnya di perkebunan masyarakat. Selanjutnya daun sungkai segar dilakukan pembersihan dengan sortasi basah.

Uji determinasi dilakukan di Universitas Andalas. Daun sungkai dibersihkan, dikeringkan, dan haluskan menggunakan grinder, dan disaring untuk menghasilkan simplisia (Muadifah et al., 2019a; Tarigan et al., 2020). Simplisia yang dihasilkan kemudian ditentukan randemen, parameter spesifik dan non-spesifik.

\section{Ekstrak Etanol Daun Sungkai}

Proses ekstrak dilakukan menggunakan serbuk kering simplisia daun dengan metode maserasi menggunakan pelarut EtOH $70 \%$. Maserasi dilakukan dengan menambahkan satu bagian simplisia ke dalam maserator dengan sepuluh bagian pelarut (1:10). Inkubasi dilakukan selama 6 jam (direndam). Maserat yang didapat lalu dipisahkan dengan filtrasi dengan menggunakan corong Buchner untuk mempercepat penyaringan. Proses maserasi diulangi dua kali dengan menggunakan jumlah dan jenis pelarut yang sama. Maserat dikumpulkan dan diuapkan menggunakan rotary evavorator untuk menghasilkan ekstrak kental. Selanjutnya ditentukan nilai randemen yang diperoleh, persen bobot (b/b) antara hasil dengan simplisia.

Partisi Ekstrak Menggunakan n-heksan

Proses partisi dilakukan dengan melarutkan ekstrak kental ke dalam etanol (9:1). Selanjutnya dimasukkan ke dalam corong pisah dan ditambahkan n-heksan dengan jumlah sebanding dengan jumlah air-etanol yang ditambahkan ke dalam ekstrak etanol (1:1). Fraksi n-heksan (lapisan atas) dipisahkan dari fraksi etanol, dan shake kembali dengan pelarut n-heksan hingga fraksi n-heksan jernih. Selanjutnya dilakukan pemekatan terhadap fraksi n-heksan menggunakan rotary evaporator pada suhu 45 ${ }^{\circ} \mathrm{C}$ selama 1-2 jam.

\section{Standarisasi Ekstrak}

Identifikasi dilakukan dengan mendeterminasi nama tumbuhan, bagian tumbuhan, dan nama ekstrak di Herbarium Laboratorium Biologi, FMIPA Universitas Andalas. Sedangkan sifat organoleptis ekstrak dilakukan menggunakan panca indera dengan mendeskripsikan bau pada ekstrak, bentuk, rasa dan warnanya (DEPKES RI, 2000).

\section{Parameter Non Spesifik Susut pengeringan}


Penentuan susut pengeringan dengan cara menimbang 1 gram ekstrak, dimasukkan ke dalam kurs porselin tertutup yang pada suhu $105^{\circ} \mathrm{C}$, selama 30 menit. Ekstrak diratakan dalam porselin, kurs digoyangkan hingga membentuk lapisan setebal 5-10 $\mathrm{mm}$, kemudian dimasukkan ke dalam oven, dikeringkan pada suhu $105^{\circ} \mathrm{C}$ hingga bobot tetap dan ditimbang. Hasilnya kemudian didinginkan dalam eksikator. Pengujian dilakukan pengulangan sebanyak 3 kali kemudian dihitung persentasenya dengan membandingkan berat hasil pengeringan dengan berat basah (DEPKES RI, 2000).

\section{Kadar Abu dan Air}

Kadar abu ditentukan dengan menimbang 1 gram ekstrak, kemudian dimasukkan ke dalam kurs porselin. Ekstrak dipijar menggunakan oven hingga mendapatkan bobot konstan (Suryadini, 2019). Sedangkan kadar air dihitung dengan cara destilasi toluene. Toluene terlebih dahulu dijenuhkan dengan air. Sebanyak 2 gram ekstrak dimasukkan ke dalam labu alas bulat dan ditambah toluene jenuh, dipanaskan selama 15 menit sampah mendidih. Setelah toluene mendidih dilakukan penyulingan dengan laju 2 tetes/detik dan 4 tetes/detik. Setelah itu dilakukan pemanasan selama 5 menit. Kemudian hasilnya didinginkan pada suhu kamar. Volume air dibaca sesudah toluene dan air memisah secara sempurna. Pengujian dilakukan pengulangan sebanyak tiga kali kemudian dihitung persentasenya (DEPKES RI, 2000).

\section{Uji Skrining Fitokimia}

Pemeriksaan senyawa metabolit sekunder ekstrak dilakukan dengan mengacu kepada penelitian sebelumnya. Pengujian dilakukan terhadap senyawa alkaloid (pereaksi Meyer), steroid dan triterpenoid (LiebermannBurchard), flavonoid (Mg dan amil alkohol), saponin (uji busa), tanin $\left(\mathrm{FeCl}_{3}\right)$ (Tarigan et al., 2020). Skrining fitokimia terhadap senyawa saponin dilakukan dengan menambahkan air (1:1), dikocok selama 1 menit, pada pengujian ekstrak menimbulkan busa lalu ditambahkan $\mathrm{HCl} 1 \mathrm{~N}$, dan busa yang terbentuk bertahan selama 1 menit dengan ketinggian $1 \mathrm{~cm}$. Skrining senyawa steroid dilakukan dengan menggunakan pereaksi Liebermann-Bouchard (asam asetat anhidrat $-\mathrm{H}_{2} \mathrm{SO}_{4}$ ).

\section{Penentuan Dosis \\ Pembuatan Sediaan Suspensi}

Terlebih dahulu dilakukan pembuatan sediaan suspensi Na-CMC, kemudian ditentukan dosis allopurinol. Dosis yang diberikan pada hewan uji adalah $10 \mathrm{mg} / \mathrm{kg}$ BB. Allopurinol digunakan sebagai kontrol positif (Hardian, Sulistriarini and Rijai, 2014).

\section{Pembuatan Induktor}

Kalium Oksonat: Kalium oksonat digunakan sebagai induktor hiperurisemia mencit dengan dosis $250 \mathrm{mg} / \mathrm{kg}$ BB (Suhendi et al, 2011). Preparasi dilakukan dengan mensuspensi kalium oksanat pada larutan Na-CMC 0.5\%, kemudian diberikan jus hati ayam secara oral untuk menginduksi hiperurisemia 0.5 $\mathrm{mL} / 20 \mathrm{gBB}$ (Cendrianti dkk., 2014).

Dosis untuk Hewan Uji: Hewan uji yang gunakan 45 ekor mencit, dibagi menjadi 5 kelompok dan dilakukan 3 kali pengulangan. Masing-masing ulangan menggunakan tiga ekor mencit, dengan pembagian kelompok pada Tabel 1.

\section{Aktivitas Antihiperursemia}

Metode pengambilan darah mengacu pada penelitian sebelumnya keluar (Amir and Purukan, 2018). Bagian ekor mencit dibersihkan menggunakan EtOH 70\%, digunting $0,2 \mathrm{~cm}$ dari ujung ekor, dan dipijat untuk mengeluarkan darah. Kadar asam urat diukur mengikuti metode penelitian sebelumnya. Hewan mencit dipuasakan makan selama \pm 18 jam. Semua mencit diukur kadar asam urat darah sebagai akdar awal (normal) (Kristiani dkk., 2013). Setelah itu mencit dibuat agar mengalami hiperurisemia, diinduksi dengan $250 \mathrm{mg} / \mathrm{KgBB}$ kalium oksonat secara intraperitonial dan 2 
$\mathrm{mL} / 200 \mathrm{grBB}$ jus hati ayam secara oral selama enam hari. Pada hari ke 7 darah mencit diambil untuk dianalisis kadar kenaikan asam urat darah setelah induksi. Mencit mengalami hiperurisemia bila kadar asam uratnya sebesar 1,7-3,0 $\mathrm{mg} / \mathrm{dL}$, adapun kadar asam urat normal pada mencit adalah $0,5-1,4 \mathrm{mg} / \mathrm{dL}$. Hari ke-tujuh dihitung sebagai hari ke 1 pemberian perlakuan pada masing-masing hewan percobaan. Pengukuran aktifitas dilakukan pada hari ke 7 dan 14. Pada saat perlakukan dosis obat, masing-masing hewan percobaan diberikan induksi jus hati ayam dan sediaan diberikan dengan frekuensi 1x sehari dan diberikan satu jam setelah induksi di pagi hari. Setelah 2 jam induksi sampel darah mencit diambil (Yulion dkk., 2017; Sonia dkk., 2020)

Tabel 1. Kelompok perlakuan uji aktivitas antihiperurisemia

\begin{tabular}{cl}
\hline Kelompok & \multicolumn{1}{c}{ Perlakuan } \\
\hline $\mathbf{1}$ & Kontrol positif, diinduksi dengan kalium oksonat dengan dosis 250 \\
$(\mathbf{K}+)$ & mg/kgBB, jus hati ayam dan pemberian allopurinol $10 \mathrm{mg} / \mathrm{kgBB}$. \\
$\mathbf{2}$ & Kontrol negatif, diinduksi dengan kalium oksonat $250 \mathrm{mg} / \mathrm{kgBB}$, jus \\
$(\mathbf{K}-)$ & hati ayam tanpa pemberian ekstrak daun sungkai. \\
$\mathbf{3}$ & diinduksi dengan kalium oksonat dengan dosis $250 \mathrm{mg} / \mathrm{kgBB}$, jus hati \\
$\mathbf{( P 1 )}$ & ayam dan pemberian ekstrak etanol daun sungkai $250 \mathrm{mg} / \mathrm{kgBB}$ \\
$\mathbf{4}$ & diinduksi dengan kalium oksonat dengan dosis $250 \mathrm{mg} / \mathrm{kgBB}$, jus hati \\
$\mathbf{( P 2})$ & ayam dan pemberian ekstrak etanol daun sungkai $500 \mathrm{mg} / \mathrm{kgBB}$ \\
$\mathbf{5}$ & diinduksi dengan kalium oksonat dengan dosis $750 \mathrm{mg} / \mathrm{kgBB}$, jus hati \\
$\mathbf{( P 3 )}$ & ayam dan pemberian ekstrak etanol daun sungkai $500 \mathrm{mg} / \mathrm{kgBB}$ \\
\hline
\end{tabular}

\section{Kadar Asam Urat Darah}

Kadar sama urat darah diukur menggunakan metode POCT, menggunakan strip test. Prinsipsnya, darah akan diabsorbsi dan menyebabkan area target berubah warna menjadi merah. Hasil akan tampak pada layar alat pengukur setelah 20 detik. Persentase penurunan kadar asam urat darah $(\% \mathrm{P})$ dianalisis menggunakan persamaan berikut:

\section{Analisa Data}

Analisa data yang digunakan untuk melihat aktivitas dari pemberian ekstrak daun sungkai ialah dengan menggunakan metode analisa variansi (ANOVA). Bila ada perbedaan antar perlakuan, akan dilanjurkan dengan uji DUNCAN. Kandungan kualitatif metabolit sekunder dianalis secara deksriptif (Apriani dkk., 2016).

\section{HASIL DAN PEMBAHASAN Determinasi Daun Sungkai}

Daun $P$. canescens dideterminasi untuk verifikasi sampel yang digunakan, apakah benar merupakan daun sungkai. Determinasi
Ket:

$$
\% \mathrm{P}=\frac{\operatorname{kadar}(-)-\operatorname{kadar}(\mathrm{p})}{\operatorname{kadar}(-)} \times 100 \%
$$

Kadar (p): kadar asam urat darah kelompok uji

Kadar (-): kadar asam urat darah kelompok kontrol negatif

daun sungkai dilakukan di Herbarium Universitas Andalas Jurusan Biologi FMIPA Universitas Andalas dengan nomor: 109/KID/ANDA/III/2019. Hasil determinasi menunjukan bahwa sampel daun sungkai yang digunakan adalah benar merupakan daun sungkai ( $P$. canescens Jack.) dari famili Lamiaceae (Imelda et al., 2007; Wahyudi dkk., 2016).

\section{Simplisia Daun P. canescens Jack.}

Sampel yang digunakan pada penelitian ini adalah daun sungkai yang telah dipreparasi terlebih dahulu (Latief et al., 2020). Setelah itu dilakukan perajangan untuk memperluas 
permukaan sampel agar sampel dapat kering dengan merata dengan lebar daun $\pm 2 \mathrm{~cm}$. Pengeringan dilakukan pada suhu $40-45^{\circ} \mathrm{C}$ menggunkan oven selama 3-4 hari untuk dapat mengurangi kadar air sehingga dapat mempertahakan mutu dari sampel dan dibatasi pada suhu tersebut agar tidak merusak senyawa kandungan kimia yang ada pada simplisi (Arel dkk., 2016; Andriani dkk., 2017).

Pada penelitian ini didapatkan serbuk simplisia yang sudah kering sebanyak $1 \mathrm{Kg}$, selanjutnya diekstrak, dan diuji kadar abu pada ekstrak. Kadar abu suatu bahan berkaitan dengan kandungan mineral bahan yang dapat berupa garam-garam organik maupun garam-garam anorganik atau sebagai senyawa komplek yang bersifat organis, dan batas kadar abu total yaitu 10\%. Dari penelitian yang dilakukan, persentase kadar abu sebesar 7,23\%, hal ini berarti simplisia daun sungkai yang digunakan sebagai sampel tidak melebihi batas syarat yang ditentukan. Selanjutnya dilakukan penentuan terhadap kandungan air simplisia, hal ini bertujuan untuk menghindari cepatnya pertumbuhan jamur dalam ekstrak. Batasan kadar air maksimal yang diperbolehkan terkandung dalam simplisia adalah $10 \%$. Persentase kadar air yang dihasilkan pada pengujian yang telah dilakukan yaitu sebesar 7,63\%, hal ini berarti kadar air yang terkandung di dalam simplisia daun sungkai tidak melebihi batas syarat yang ditentukan. Adapun hasil perhitungan dari nilai rendemen simplisia daun sungkai yaitu sebesar 22,22\% (DepkesRI, 2000).

\section{Rendemen Ekstrak Daun Sungkai}

Ekstraksi dilakukan dengan

menggunakan serbuk simplisia daun sungkai sebanyak $0,99 \mathrm{~kg}$ dan menggunakan pelarut organik etanol $70 \%$, diketahui bahwa etanol dengan konsentrasi $70 \%$ bersifat magic solvent karena dapat bereaksi dengan bahan yang bersifat polar, semi polar maupun non polar sehingga penggunaan etanol diharapkan dapat menarik semua kandungan senyawa kimia pada simplisia daun sungkai, terutama kandungan senyawa flavonoid yang diketahui dapat beraktivitas sebagai antihiperurisemia, selain itu diketahui bahwa untuk ekstraksi suatu bahan yang akan digunakan sebagai bahan obat sebaiknya menggunakan etanol karena etanol cukup aman. Ekstrak kental etanol $70 \%$ yang didapatkan yaitu sebanyak 85 gram, dan nilai rendemen yang diperoleh adalah $8,5 \%$

Selanjutnya dilakukan partisi pada ekstrak kental etanol dengan menggunakan pelarut n-heksan, partisi dilakukan dengan tujuan untuk memisahkan analit yang dituju dari penganggu dengan cara melakukan partisi sampel antar pelarut yang tidak saling campur. Salah satu fasenya seringkali berupa air dan fase yang lain adalah pelarut organik. Senyawa-senyawa yang bersifat polar akan ditemukan di dalam fase air, sementara senyawa-senyawa yang bersifat hidrofobik akan masuk pada pelarut organik. Hasil ekstrak kental etanol daun sungkai yang telah dilakukan partisi dengan menggunakan nheksan yaitu sebanyak 35 gram, dengan nilai rendemen yaitu $41,17 \%$, dibanding total ekstrak. Sejalan dengan itu, bahwa nilai rendemen yang tinggi menunjukkan banyaknya komponen bioaktif yang terkandung di dalamnya.

\section{Ekstrak Daun P. canescens Jack Parameter Non Spesifik}

Parameter non fisik merupakan parameter aspek kimia, mikrobiologi, dan fisis yang mempengaruhi keamanan konsumen dan stabilitas. Hasil dari pengujian parameter non spesifk yang dilakukan tercantumkan dalam Tabel 2 (Saifuddin, 2011).

Tabel 2. Hasil uji parameter non spesifik

\begin{tabular}{cc}
\hline Parameter (\%) & Hasil $(\%)$ \\
\hline Kadar Air & $1,98 \%$, \\
Kadar Abu & $0,94 \%$, \\
Susut Pengeringan & $1,13 \%$, \\
Rendemen & $41,17 \%$ \\
\hline
\end{tabular}

Uji non spesifik ekstrak daun sungkai seperti terlihat pada Tabel 2 meliputi, uji kadar abu, kadar air dan susut pengeringan. 
Uji kadar abu bertujuan untuk mendapatkan gambaran mineral yang terkandung dalam sampel, berasal dari proses awal sampai terbentuknya ekstrak. Pada prinsipnya pengujian kadar abu dilakukan aitu dengan memanaskan ekstrak pada temperatur saat senyawa organik dan turunannya terdestruksi dan menguap sehingga tinggal unsur mineral dan anorganik. Abu adalah zat anorganik atau hasil pembakaran suatu bahan organik. Kadar abu suatu bahan berkaitan dengan kandungan mineral bahan yang dapat berupa garamgaram organik maupun garam-garam anorganik atau sebagai senyawa komplek yang bersifat organis. kadar abu total ekstrak kental yaitu <8\%). Persentase kadar abu ekstrak etanol $70 \%$ daun sungkai yang sudah dilakukan partisi dengan pelarut n-heksan ialah sebesar 0,94\%. Hasil menunjukkan kadar abu pada sampel daun sungkai yang digunakan tidak lebih besar dari standar yang ditentukan (DepkesRI, 2000.

Penentuan kadar air bertujuan untuk menghindari cepatnya pertumbuhan jamur dalam ekstrak. Batas kadar air ekstrak yang memenuhi syarat adalah < 10\% (DepkesRI, 2000). Persentase kadar air yang dihasilkan pada pengujian yang telah dilakukan yaitu sebesar $1,98 \%$ pada ekstrak kering, hal ini berarti kadar air yang tekandung di dalam ekstrak etanol daun sungkai tidak melebihi batas yang ditentukan sehingga ekstrak dapat lebih tahan lama dan terhindar dari reaksi enzimatis selama penyimpanan.

Uji parameter susut pengeringan dilakukan untuk memperlihatkan berapa banyak senyawa yang terkandung pada ekstrak dan hilang atau mudah menguap pada proses pengeringan. Bobot penyusutan atau susut pengeringan menjadi parameter suatu ekstrak untuk menjaga kualitas agar terhindar dari pertumbuhan jamur (Safitri, 2008). standar yang ditetapkan oleh Depkes RI (2008) yaitu menyatakan bahwa susut pengeringan yang baik adalah $<10 \%$. Persentase susut pengeringan dari ekstrak etanol daun sungkai yaitu $1,13 \%$, ini menunjukkan bahwa susut pengeringan sampel ekstrak masih memenuhi standar yang ditentukan.

\section{Parameter Spesifik}

Ekstrak kental yang diperoleh selanjutnya dilakukan uji parameter standar ekstrak. Penentuan parameter spesifik adalah aspek kandungan kimia kualitatif dan aspek kuantitatif kadar senyawa kimia yang bertanggung jawab langsung terhadap aktivitas farmakologis tertentu. Uji parameter spesifik seperti pada Tabel 3 meliputi, identifikasi terhadap bentuk, warna, bau, dan rasa ekstrak (DepkesRI, 2000).

\section{Senyawa Metabolit Sekunder}

Skrining fitokimia dilakukan untuk mengetahui kandungan senyawa metabolit sekunder di dalam daun sungkai. Pengujian dilakukan dengan cara menambahkan ekstrak kedalam tabung reaksi dan menambahkan reagen-reagen yang sesuai untuk pengujian pada masing-masing senyawa yang akan diamati, lalu dilihat perubahan atau kimia yang terbentuk setelah menambahkan reagen pada ekstrak mengacu pada penelitian sebelumnya (Muadifah et al., 2019b; Tarigan et al., 2020).

Hasil uji fitokimia pada ekstrak etanol daun $P$. cannescens positif mengandung senyawa golongan flavonoid, alkaloid, fenolik, steroid, saponin, dan tannin (Table 4). Hasil ini sesuai dengan penelitian sebelumnya (Pada et al., 2013; Ahmad et al., 2017; Fransisca, Kahanjak and Frethernety, 2020)

Tabel 3. Hasil uji parameter spesifik

\begin{tabular}{ll}
\hline \multicolumn{1}{c}{ Parameter Ekstrak } & \multicolumn{1}{c}{ Hasil } \\
\hline Identitas Ekstrak & \\
Nama Ekstrak & Peronema canescens Jack. Extractum \\
Nama Latin Tumbuhan & Peronema canescens Jack. \\
\hline
\end{tabular}




\begin{tabular}{ll}
\hline $\begin{array}{l}\text { Bagian Tumbuhan yang } \\
\text { digunakan }\end{array}$ & Daun \\
Nama Indonesia Tanaman & Sungkai \\
Nama Lokal & Jati Sabrang, Longkai \\
Organoleptis Ekstrak & \\
Bentuk & Kental \\
Warna & Hijau \\
Bau & Aaromatik \\
Rasa & Kelat, Pahit \\
\hline
\end{tabular}

Tabel 4. Hasil skrining fitokimia ekstrak etanol daun $P$. cannescens

\begin{tabular}{cc}
\hline Jenis senyawa & Hasil \\
\hline Alkaloid & + \\
Flavonoid & + \\
Saponin & + \\
Steroid & + \\
Triterpenoid & - \\
Fenolik & + \\
tanin & + \\
\hline
\end{tabular}

Keterangan :

$(+)=$ Positif mengandung metabilit sekunder

$(-)=$ Negatif mengandung metabolit sekunder

\section{Aktivitas Antihiperurisemia}

Aktivitas antihiperurisemia ekkstrak dianalisis dengan menggunakan mencit putih jantan (Mus musculus) dengan berat badan sekitar 25-35 gram yang telah dibuat hiperurisemia. Mencit uji diadaptasikan terlebih dahulu selama tujuh hari pada kondisi laboratorium dan ditimbang berat badan untuk melihat bahwa tidak terjadi perubahan sampai dengan 10\% (BPOM, 2014). Salah satu alasan penggunaan mencit putih karena karakteristik genetik, biologi, dan perilaku relatif mirip dengan manusia.

Kondisi hiperurisemia mencit diinduksi dengan $250 \mathrm{mg} / \mathrm{KgBB}$ kalium oksonat, yang berperan sebagai inhibitor enzim urikase. Enzim urikase dapat mencegah asam urat menjadi allantoin sehingga akan meningkatkan kadar asam urat. Penghambatan enzim urikase oleh kalium oksonat menyebabkan asam urat akan tertumpuk dan tidak tereliminasi dalam bentuk urin (Hidayah et al., 2018). Inhibitor enzim bersifat irreversible non-kompetititf dan tidak bersifat toksik. Menurut penelitian terdahulu, potasium oxonate merupakan inhibitor enzim urikasi yang efektif secara invivo (Ibrahim et al., 2020).

Selain menggunakan kalium oksonat, penelitian ini menggunakan jus hati ayam digunakan sebagai agen penginduksi hiperurisemia, dengan mengandung kadar purin yang tinggi mencapai 150-1000 mg /100 gram bahan makanan (Murugaiyah and Chan, 2009; Krisyanella et al., 2019). Kadar purin yang tinggi pada makanan akan berperan dalam meningkatkan kadar asam urat. Secara umum, peningkatan asam urat dalam darah disebabkan oleh basa purin baik adenin ataupun guanin. Adenin dapat diubah menjadi hypoxantine, sedangkan guanine dirubah menjadi xantine. Hypoxantine selanjutnya dikonversi menjadi xanthine oleh enzim xanthine oxydase dan menjadi asam urat.

Penelitian ini menggunakan allopurinol sebagai kontrol positif $(\mathrm{K}+)$, karena telah digunakan secara umum sebagai obat asam urat. Allopurinol merupakan derivat asam nukleat dan memiliki kemampuan menghambat proses sintesis asam urat. Allopurinol adalah inhibitor yang spesifik dan substrat untuk enzim xantin oksidase. Allopurinol tergolong sebagai senyawa analog purin yang dimetabolisme oleh xantin oksidase menjadi oksipurinol (alloxantin) yang dapat menghambat aktivitas enzim xantin oksidase.

Kelompok kontrol negatif hanya diberikan $\mathrm{Na}-\mathrm{CMC}$ dengan konsentrasi $0,5 \%$, sebagai pembanding digunakan kontrol negatif terhadap mencit tanpa diberi obat dengan 
kadar asam urat darah hewan uji yang diberikan obat sintetik dan ekstrak daun sungkai, karena Na-CMC diketahui tidak memiliki efek farmakologis sehingga tidak berpengaruh terhadap penurunan kadar asam urat darah hewan uji. Pada penelitian ini digunakan beberapa dosis ekstrak daun sungkai yang berbeda pada setiap kelompok perlakuan, dimana kelompok perlakuan 1 (P1) menggunakan dosis $125 \mathrm{mg} / \mathrm{KgBB}$, kelompok perlakuan 2 (P2) menggunakan dosis $250 \mathrm{mg} / \mathrm{KgBB}$, dan kelompok perlakuan 3 (P3) menggunakan dosis 500 $\mathrm{mg} / \mathrm{KgBB}$.

Hasil pengukuran penurunan kadar asam urat pada darah mencit berdasarkan kelompok uji dapat dilihat pada Tabel 5. Pada kelompok kontrol positif hasil data rata-rata kadar darah awal hewan uji yaitu 3,31 mg/dL. Umumnya kadar normal asam urat mencit adalah 0,5-3,3
mg/dL (Hardian, Sulistriarini and Rijai, 2014). Hasil pengambilan darah setelah dilakukan induksi selama enam hari berturutturut dapat dilihat pada Tabel 3. Hasil penelitian kami menunjukan adanya peningkatan kadar asam urat darah hewan uji sampai lebih dari $50 \%$ peningkatan, dengan rata-rata kadar asam urat setelah diinduksi berkisar $8.73 \mathrm{mg} / \mathrm{dl}$. Menurut penelitian sebelumnya, bahwa apabila kadar asam urat $>4.38 \mathrm{mg} / \mathrm{dL}$, maka mencit dikategorikan mengalami hiperurisemia. Pengukuran darah mencit pasca pemberian allopurinol pada hari ke-14 menunjukkan rata-rata nilai penurunan asam urat mencapai 3,98 mg/dL (Tabel 6). Persen penurunan kadar asam urat pada kelompok K+ sampai dengan 40,16\%.

Tabel 5. Kadar asam urat darah pada mencit

\begin{tabular}{ccc}
\hline $\begin{array}{c}\text { Kelompok } \\
\text { Perlakuan }\end{array}$ & \multicolumn{2}{c}{ Kadar asam urat } \\
\cline { 2 - 3 } & Hari ke- & Hari ke- 14 \\
\hline K+ & $8,73^{\mathrm{a}} \pm 0,44$ & $3,98^{\mathrm{a}} \pm 0,24$ \\
K- & $8,71^{\mathrm{a}} \pm 0,45$ & $6,66^{\mathrm{c}} \pm 0,06$ \\
P1 & $8,84^{\mathrm{a}} \pm 0,42$ & $5,35^{\mathrm{b}} \pm 0,20$ \\
P2 & $7,51^{\mathrm{a}} \pm 0,33$ & $4,97^{\mathrm{b}} \pm 0,25$ \\
P3 & $8,52^{\mathrm{a}} \pm 0,53$ & $4,08^{\mathrm{a}} \pm 0,20$
\end{tabular}

$\overline{\text { Keterangan: Superskrip yang berbeda menunjukkan perbedaan yang nyata }(\mathrm{p}<0.05)}$.

Data aktivitas antihiperurisemia selanjutnya dianalisis secara statistik menggunakan uji One-Way ANOVA dengan taraf kepercayaan 95\%. Hasil dari uji One Way ANOVA menunjukkan $\mathrm{p}=0,000$ yang berarti nilai $\mathrm{p}<0,05$. Selanjutnya diuji lanjutan dengan menggunakan uji Duncan. Hasil dari uji Duncan menunjukkan bahwa pada tabel penurunan kadar asam urat pada kelompok $\mathrm{K}+$ menunjukkan ada pengaruh perlakuan terhadap penurunan kadar asam urat darah hewan uji.

Pada kelompok kontrol negatif, pengukuran kadar asam urat awal hewan uji yaitu sebesar 3,53 $\mathrm{mg} / \mathrm{dL}$, setelah diberikan induksi selama 6 hari kadar asam urat naik menjadi $8,71 \mathrm{mg} / \mathrm{dl}$, hal ini berarti induksi berhasil meningkatkan kadar asam urat sampai lebih dari 50\%, setelah diinduksi hewan uji hanya diberikan $\mathrm{Na} \mathrm{CMC}$ dengan konsentrasi $0,5 \%$ setiap hari sampai hari ke 14. Selanjutnya dilakukan uji statistik seperti pada $\mathrm{K}+$, pada uji lanjut menggunakan metode Duncan dilihat pada tabel penurunan kadar asam urat K- memiliki nilai $\mathrm{p}>0,05$, hal ini berarti $\mathrm{K}$ - memiliki pengaruh terhadap kadar asam urat hewan uji, namun K- berbeda nyata dengan $\mathrm{K}+$.

Tabel 6. Persentase penurunan kadar asam urat darah pada mencit. 


\begin{tabular}{cccc}
\hline \multirow{2}{*}{$\begin{array}{c}\text { Kelompok } \\
\text { Perlakuan }\end{array}$} & \multicolumn{2}{c}{ Kadar asam urat hari ke- } & \multirow{2}{*}{ Persentase (\%) } \\
\cline { 2 - 3 } & Hari ke- 7 & Hari ke- 14 & \\
\hline K+ & $8,73^{\mathrm{a}} \pm 0,44$ & $3,98^{\mathrm{a}} \pm 0,24$ & $40,16 \%$ \\
P1 & $8,84^{\mathrm{a}} \pm 0,42$ & $5,35^{\mathrm{b}} \pm 0,20$ & $25,33 \%$ \\
P2 & $7,51^{\mathrm{a}} \pm 0,33$ & $4,97^{\mathrm{b}} \pm 0,25$ & $19,66 \%$ \\
P3 & $8,52^{\mathrm{a}} \pm 0,53$ & $4,08^{\mathrm{a}} \pm 0,20$ & $38,66 \%$ \\
\hline
\end{tabular}

Keterangan: Superskrip yang berbeda menunjukkan perbedaan yang nyata $(\mathrm{p}<0.05)$.

Pada P1 menggunakan dosis ekstrak daun sungkai $125 \mathrm{mg} / \mathrm{KgBB}$, hasil data pengukuran kadar darah awal hewan uji adalah 3,45 $\mathrm{mg} / \mathrm{dL}$. Selanjutnya dilakukan pengambilan darah setelah induksi, hasil pengambilan darah menunjukkan terjadi peningkatan kadar asam urat darah mencit lebih dari 50\% peningkatan, dengan rata-rata kadar asam urat hewan uji setelah induksi adalah $8,84 \mathrm{mg} / \mathrm{dL}$. Hal ini berarti penginduksian dapat dikatakan berhasil. Hasil data setelah pemberian ekstrak etanol daun $P$. cannescens sampai hari ke 14 adalah 5,355 mg/dL. Dari hasil yang didapatkan, diketahui bahwa setelah 14 hari pemberian ekstrak $P$. cannescens menunjukan bahwa adanya aktivitas antihiperurisemia ekstrak dengan menurunkan kadar asam urat darah sebesar 19,66\%. Hasil uji One Way ANOVA dan uji lanjut dengan metode Duncan, menunjukkan bahwa kelompok P1 memiliki nilai $\mathrm{p}>0,05$. Aktivitas antihiperurisemia P1 berbeda nyata dengan $\mathrm{K}+$, $\mathrm{K}-$, dan $\mathrm{P} 3$, tetapi tidak berbeda signifikan dengan kelompok P2, persentase menunjukkan penurunan kadar asam urat pada P1 tidak sebesar pada P2 dan P3 namun pada dosis $125 \mathrm{mg} / \mathrm{KgBB}$ ekstrak daun sungkai terbukti dapat menurunkan kadar asam urat darah, hal ini terjadi dikarenakan adanya senyawa flavonoid yang terkandung di dalam ekstrak daun sungkai. Senyawa flavonoid ditemukan memiliki aktivitas antihiperurisemia dan menghambat aktivitas enzim XO dan menurunkan kadar asam urat darah.

Pada kelompok P2 menggunakan dosis ekstrak daun sungkai $250 \mathrm{mg} / \mathrm{KgBB}$, data kadar asam urat darah awal adalah 3,33 $\mathrm{mg} / \mathrm{dL}$, setelah dilakukan induksi kadar asam urat darah hewan uji adalah 7,51 mg/dL (hiperurisemia). Selanjutnya diberikan ekstrak selama 14 hari, data pengukuran kadar asam urat adalah 4,97 mg/dL, hal ini berarti ekstrak daun sungkai beraktivitas menurunkan kadar asam urat mencapai $25,33 \%$ (penurunan).

Analisis data secara statistik dengan uji One Way ANOVA dan uji lanjut dengan metode Duncan menunjukkan data P2 memiliki nilai $\mathrm{p}>0.5$, kelompok $\mathrm{P} 2$ berbeda nyata dengan $\mathrm{K}+, \mathrm{K}-$, dan $\mathrm{P} 3$, tetapi tidak signifikan berbeda dengan P1. P2 memiliki efektivitas lebih tinggi dibanding P1, tetapi tidak sama dengan efektivitas kelompok P3. Hal ini dikarenakan dosis ekstrak daun sungkai pada kelompok P2 lebih besar dibandingkan pada kelompok P1. Senyawa flavonoid mampu menurunkan kadar asam urat dengan menghambat aktivitas XO pada basa purin. Selain senyawa flavonoid, diketahui bahwa senyawa lain, seperti alkaloid yang terkandung di dalam daun sungkai juga beraktivitas menurunkan kadar asam urat darah dengan cara menginhibisi xantin oksidase, menghambat sintesis asam urat, serta sebagai antiinflamasi (Cendrianti dkk., 2014; Ahmad et al., 2017; Fransisca dkk., 2020)

Pada kelompok P3 yang menggunakan dosis ekstrak daun sungkai $500 \mathrm{mg} / \mathrm{KgBB}$, kadar asam urat darah awal mencit adalah $3,34 \mathrm{mg} / \mathrm{dL}$, dan mencapai $8,52 \mathrm{mg} / \mathrm{dL}$ setelah diinduksi. Induksi berhasil meningkatkan kadar asam urat darah sehingga menjadi keadaan hiperurisemia, selanjutnya diberikan ekstrak daun sungkai selama 14 hari, data pengukuran darah setelah diberikan ekstrak daun sungkai adalah 4,08 mg/dL, hal ini berarti daun sungkai beraktivitas 
menurunkan kadar asam urat darah, adapun persen penurunan pada kelompok P3 hampir mendekati persen penurunan pada kelompok $\mathrm{K}+$ yaitu sebesar $38,66 \%$. Selanjutnya data dianalisis statistik dengan uji One Way ANOVA dan uji lanjutan metode Duncan. Hasil uji menyatakan bahwa P3 dapat menurunkan kadar asam urat darah pada uji Duncan memiliki nilai $p>0,5$, yang menunjukkan kelompok P3 berbeda nyata dengan kelompok K-, kelompok P1, dan P2, namun tidak berbeda signifikan dengan kelompok $\mathrm{K}+$. Hal ini berarti bahwa kelompok P3 hampir mendekati efektivitas yang sama seperti pada kelompok $\mathrm{K}+$ menurunkan kadar asam urat darah. Sehingga dapat dikatakan bahwa kelompok P3 yang menggunakan dosis $500 \mathrm{mg} / \mathrm{KgBB}$ dapat memberikan aktivitas penurunan kadar asam urat paling efektif dibandingkan dengan kelompok P1 yang menggunakan dosis 125 $\mathrm{mg} / \mathrm{KgBB}$ dan kelompok P2 yang menggunakan dosis $250 \mathrm{mg} / \mathrm{KgBB}$, hal ini diduga karena jumlah kandungan senyawa aktif pada kelompok P3 lebih banyak dibandingkan $\mathrm{P} 1$ dan $\mathrm{P} 2$.

Penelitian sebelumnya melaporkan tumbuhan yang satu famili $P$. cannescens yaitu daun kumis kucing (Orthosiphon stamineus Benth.). Senyawa flavonoid ekstrak Orthosiphon stamineus dapat menurunkan kadar asam urat darah. Hasil yang sama ditemukan dalam penelitian ini, senyawa flavonoid daun sungkai dapat menurunkan kadar asam urat darah mencit. Dosis paling efektif yang digunakan dari ekstrak Orthosiphon stamineus adalah 500 $\mathrm{mg} / \mathrm{KgBB}$. Pada penelitian ini digunakan dosis ekstrak etanol $P$. cannescens yang paling tinggi kemampuannya dalam menurunkan kadar asam urat darah adalah dosis $500 \mathrm{mg} / \mathrm{KgBB}$. Dalam penelitian lainnya dilaporkan daun kumis kucing telah terbukti memberikan daya hambat terhadap xantin oksidase karena diketahui memiliki nilai $\mathrm{IC}_{50}$ sebesar 92,14 ug/mL. Aktivitas daya hambat enzim XO senyawa bioaktif didasarkan pada nilai $\mathrm{IC}_{50}$. Senyawa dikatakan aktif bila memiliki nilai $\mathrm{IC}_{50}$ kurang dari $100 \mu \mathrm{g} / \mathrm{mL}$. Senyawa flavonoid memiliki beberapa potensi sebagai senyawa obat terhadap penyakit iskemik dan gout dengan menurunkan konsentrasi asam urat dan penangkapan aktivitas superoksida pada jaringan manusia. Senyawa bioaktif lain yang terdapat pada daun sungkai yang juga memiliki aktivitas antihiperurisemia ialah alkaloid. Senyawa alkaloid mampu menghambat aktivitas enzim XO, sehingga menghambat sintesis asam urat. Selain itu senyawa alkaloid daun Sungkai juga memiliki aktivitas anti-inflamasi. Kolkisin merupakan salah satu senyawa golongan alkaloid yang bersifat antihiperurisemia. Sebagai antiinflamasi senyawa kolkisin berperan dalam menghambat kemotaksis sel radang dalam penyembuhan pada radang akibat adanya konsentrasi asam urat yang berlebih dalam darah. Selain itu juga dapat menyebabkan aktivitas enzim XO dalam proses degradasi hipoxantin dan xantin menjadi asam urat terhambat (Murugaiyah and Chan, 2009; Li et al., 2017; Song et al., 2018; Bernardes et al., 2019). Selain itu juga diketahui bahwa senyawa rhombifolin golongan alkaloid diduga dapat berperan sebagai inhibitor enzim $\mathrm{XO}$ dan XDH (Xantin dehidrognase), sehingga dapat mencegah hiperurisemia hati secara in vivo.

Senyawa polifenol pada daun sungkai juga diketahui dapat menurunkan resiko terjadinya penyakitt gout, dengan menurunkan kadar asam urat darah dalam plasma Polifenol sebagai antioksidan dapat berpengaruh terhadap penyembuhan penyakit asam urat. Sedangkan senyawa golongan tannin dari secara umum diketahui memiliki aktivitas sebagai antioksidan dan dapat mengikat senyawa radikal bebas pada reaksi biosintesis asam urat dari purin. Selain itu tannin juga bersifat astrigensi, menciutkan selaput lender. Tannin merupakan derivate dari saponin, yang juga dapat berperan sebagai antihiperurisemia dengan menghambat enzim XO. Eksplorasi secara spesifik peran senyawa yang terlibat dan 
efektivitasnya masih perlu dilakukan untuk mendapatkan studi yang lebih komprehensif.

\section{KESIMPULAN}

Dalam penelitian ini kami berhasil mengekstrak senyawa bioaktif dari daun $P$. cannescens. Ekstrak etanol P. cannescens memiliki aktivitas antihiperurisemia dengan menurunkan kadar asam urat darah mencit. Selain itu pada penelitian ini diketahui pada dosis $500 \mathrm{mg} / \mathrm{KgBB}$ memberikan aktivitas yang paling baik dalam menurunkan kadar asam urat darah mencit hiperurisemia.

\section{Daftar Pustaka}

Ahmad, I. 2017. Pharmacognostic and cytotoxicity evaluation of indonesia native plant of Piper acre blume leaves (Piperaceae), Pharmacognosy Journal, 9(3), pp. 400-404. doi: 10.5530/pj.2017.3.68.

Ahmad, I. and Ibrahim, A. 2013. Bioaktivitas ekstrak metanol dan fraksi n-heksan daun sungkai (Peronema canescens . Jack) terhadap larva udang (Artemia salina Leach), Journal of Chemical Information and Modeling, 53(9), pp. 1689-1699.

Alpiansyah, A. 2015. Antihyperuricemia potential of Sida rhombifolial. as a treatment for gout', J Majority |, 4(9), pp. 9-13.

Amir, M., and Purukan, J.I.A. 2018. Uji efektifitas ekstras etanol buah naga putih (Hylocereus undatus) terhadap penurunan kadar asam urat darah pada mencit (Mus musculus), Jurnal Ilmu Kefarmasian Indonesia, 16(2), p. 166. doi: 10.35814/jifi.v16i2.536.

Apriani, A. A., Prabowo, W. C. and Ibrahim, A. 2016. Efek antihiperurisemia ekstrak etanol daun mahkota dewa (Phaleria macrocarpa Scheff. Boerl.) pada mencit putih (Mus musculus), Prosiding Seminar Nasional Tumbuhan Obat Indonesia Ke-50, (April 2016), pp. 68-70.

Arafat, O.M, 2008. Studies on diuretic and hypouricemic effects of Orthosiphon stamineus methanol extracts in rats, Journal of Ethnopharmacology, 118(3), pp. 354-360. doi: 10.1016/j.jep.2008.04.015.

Arel, A., Dira, D. and Setiawati, A. 2016. Isolasi Senyawa utama kulit batang tumbuhan pinus dari ekstrak etil asetat, Jurnal Ilmiah Farmasi, 12(2), pp. 60-65. Available at: http://journal.uii.ac.id/index.php/JIF.

Bernardes, A.C.F.P.F. 2019. In vivo anti-hyperuricemic activity of sesquiterpene lactones from Lychnophora species, Revista Brasileira de Farmacognosia, 29(2), pp. 241-245. doi: 10.1016/j.bjp.2018.12.008.

BPOM. 2014. Peraturan Kepala Badan Pengawas Obat dan Makanan Republik Indonesia Nomor 7 Tahun 2014 Tentang Pedoman Uji Toksisitas Nonklinik Secara In Vivo. Edited by BPOM. Jakarta: Badan Pengawas Obat dan Makanan Republik Indonesia.

Cendrianti, F., Muslichah, S. and Ulfa, E.U. 2014. Uji Aktivitas antihiperurisemia ekstrak nheksana, etil asetat, dan etanol $70 \%$ daun tempuyung (Sonchus arvensis L.) pada mencit jantan hiperurisemia, e-Jurnal Pustaka Kesehatan, 2(2), pp. 205-210.

Depkes RI. 2000. Parameter standar umum ekstrak tumbuhan obat, Direktorat Jenderal Pengawas Obat dan Makanan. Edited by Departemen Kesehatan Republik Indonesia. Jakarta: Departemen Kesehatan Republik Indonesia. 
Depkes RI. 2000. Parameter standar umum ekstrak tumbuhan obat. jakarta: Direktorat Jenderal Pengawas Obat dan Makanan, Depkes RI.

Dwitiyanti, Dewanti, E. and Rachmania, R.A. 2019. Anti-hyperuricemia effect of water fraction cinnamon (Cinnamomum burmannii (Ness \& T. Ness) Blume) on white male rats, Proceeding of the 1st Muhammadiyah International Conference on Health and Pharmaceutical Development (MICH-PhD), 1(1), pp. 102-106. doi: $10.5220 / 0008240101020106$.

Fenny, A., Sundaryono, A., and Nurhamidah. 2017. Uji Aktivitas antiplasmodium fraksi nheksana daun Peronema canescens terhadap Mus musculus, Alotrop: Jurnal Pendidikan dan Ilmu Kimia, 1(1), pp. 33-38.

Fitri, R.A., Sumarmin, R. and Yuniarti, E. 2017. Effect of mangosteen skin extract (Garcinia mangostana L.) on males mice (Mus musculus L. Swiss Webster) uric acid level, BioSciences, 1(2), pp. 53-61. doi: https://doi.org/10.24036/bsc.v1i2.7718.

Fitrya and Muharni. 2014. An antihyperuricemia effect of ethanol extract of tunjuk langit rhizome (Helmynthostachys zaylanica Linn Hook ) on Swiss male mice, Tradisional Medicine Journal, 19(1), pp. 14-18.

Fransisca, D., Kahanjak, D. N. and Frethernety, A. 2020. Uji aktivitas antibakteri ekstrak etanol daun sungkai (Peronema canescens Jack) terhadap pertumbuhan Escherichia coli dengan metode difusi cakram Kirby-Bauer, Jurnal Pengelolaan Lingkungan Berkelanjutan (Journal of Environmental Sustainability Management), 4(1), pp. 460-470. doi: 10.36813/jplb.4.1.460-470.

Hardian, Sulistriani, R., and Rijai, L. 2014. Aktivitas antihiperurisemia ekstrak etanol daun lada (Piper ningrium L) pada mencit (Mus musculus L.), J. Trop. Pharm. Chem., 2(5), pp. 219-232.

Hidayah, N. 2018. Uji efektifitas antihiperurisemia ekstrak daun salam (Syzygium polyanthum Wight) terhadap mencit jantan yang diinduksi jus hati ayam dan kalium oksonat, Jurnal Saintika, 18(1), pp. 24-31.

Ibrahim, N. 2020. Phytochemical analysis and antihyperuricemic activity of ethanolic extract of Moringa oleifera seeds, Pharmacognosy Journal, 12(6), pp. 1698-1704. doi: 10.5530/pj.2020.12.229.

Imelda, M. 2007. Keseragaman genetik bibit sungkai (Peronema canescens Jack ) hasil kultur jaringan tissue culture', 8 , pp. 54-57.

Kristiani, R. D., Rahayu, D. dan Subarnas, A. 2013. Aktivitas antihiperurisemia ekstrak etanol akar pakis tangkur (Polypodium feei) pada mencit jantan, Bionatura-Jurnal Ilmu-Ilmu Hayati dan Fisik, 15(3), pp. 156-159.

Kusuma, A., Mahardian, Wahyuningrum, R. and Wisyati, T. 2014. Aktivitas antihiperurisemia ekstrak etanol herba pegagan pada mencit jantan dengan induksi kafein, Pharmacy, 11(01), pp. 62-74.

Latief, M. 2020. Potential tracking of cytotoxic activities of mangrove perepate (Sonneratia alba) root extract as an anti-cancer candidate, Pharmacology and Clinical Pharmacy Research, 5(2), pp. 48-55. doi: 10.15416/pcpr.v5i2.26790. 
Li, L. 2017. Anti-gouty arthritis and antihyperuricemia effects of sunflower (Helianthus annuus) head extract in gouty and hyperuricemia animal models, BioMed Research International, 2017. doi: 10.1155/2017/5852076.

Muadifah, A. 2019a. Studi aktivitas ekstrak etanol dan sediaan gel daun melinjo (Gnetum gnemon L) sebagai antibakteri terhadap Staphylococcus aureus, Chempublish Journal Vol. 4 No. 2 (2019) 89 - 100, 4(2), pp. 89-100.

Murugaiyah, V. and Chan, K.L. 2009. Mechanisms of antihyperuricemic effect of Phyllanthus niruri and its lignan constituents, Journal of Ethnopharmacology, 124(2), pp. 233-239. doi: 10.1016/j.jep.2009.04.026.

Pada, I. 2013. The potential test of sungkai young leaves (Peronema canescens) to maintain goodhealth (immunity) in mice (Mus musculus), Seminar Nasional XI Pendidikan Biologi FKIP UNS Biologi, Sains, Lingkungan, dan Pembelajarannya, pp. 245-250.

Roumeliotis, S. 2019. Dietary antioxidant supplements and uric acid in chronic kidney disease: a review, Nutrients, 11(8), pp. 1-18. doi: 10.3390/nu11081911.

Saifuddin, A. 2011. Metode Penelitian. Yogyakarta: Pustaka Pelajar.

Soetisna, U. 2005. Study on seed anatomy of sungkai (Peronema canescens Jack); a viability perspective, Biodiversitas, Journal of Biological Diversity, 6(4), pp. 288-291. doi: 10.13057/biodiv/d060416.

Song, S.H. 2018. Ethanol extract of Cudrania tricuspidata leaf ameliorates hyperuricemia in mice via inhibition of hepatic and serum xanthine oxidase activity, Evidence-based Complementary and Alternative Medicine, 2018. doi: 10.1155/2018/8037925.

Sonia, R., Yusnelti, Y. and Fitrianingsih, F. 2020. Efektivitas ekstrak etanol daun durian (Durio zibethinus (Linn.)) sebagai antihiperurisemia, Jurnal Kefarmasian Indonesia, 10(2), pp. 130-139. doi: 10.22435/jki.v10i2.2148.

Suhendi, A. 2011. Aktivitas antihiperurisemia ekstrak air jinten hitam (Coleus ambonicus Lour) pada mencit jantan galur balb-c dan standardisasinya, Majalah Farmasi Indonesia, 22(2), pp. 77-84.

Suryadini, H. 2019. Uji parameter standar dan penapisan fitokimia pada daun steril kelakai (Stenochlaena palustris (Burm . f .) Bedd), Jurnal Ilmiah Farmasi Famasyifa, 2(1), pp. 40-51.

Tarigan, I.L. 2020. Phytochemical screening and quantitative analysis of coleus arthropurpureus ethyl acetate fraction and antibacterial activity agains Staphylococcus aureus, ALKIMIA: Jurnal Ilmu Kimia dan Terapan, 4(1), pp. 17-23. doi: 10.19109/alkimia.v4i1.5123.

Wahyudi, Mojiol, A., and Muttaqin, Z. 2016. Growth and yield analysis of sungkai (Peronema canescens Jack.) in Kalimantan Indonesia, Borneo Science, 37(March), pp. 72-81.

Wahyuningsih, S. 2016. Antihyperuricemia activity of the ethanol extract of Roselle calyx and its fraction (Hibiscus sabdariffa Linn) on male wistar rats, International Journal of Pharmacy and Pharmaceutical Sciences, 8(3), pp. 278-280. 
Yulion, R., Suhatri and Arifin, H. 2017. Pengaruh hasil fraksinasi ekstrak etanol daun ladolado (litsea cubeba Pers) terhadap kadar asam urat serum darah mencit putih jantan tinggi asam urat, Jurnal Sains dan Teknologi Farmasi, 19(1). 